\title{
Socioeconomic status and childhood atopy
}

\author{
KITAW DEMISSIE MD MPH, PIERRE ERNST MD MSc, MARGARET R BECKLAKE MD \\ Respiratory Epidemiology Unit, McGill University, Montreal, Quebec
}

K Demissie, P ERnst, MR BeCKLAKE. Socioeconomic status and childhood atopy. Can Respir J 1996;3(1):5357.

BACKGROUND: Variation in the prevalence of allergic disorders among socioeconomic groups could be due either to differences in the type of allergens encountered or to actual differences in susceptibility to sensitization to any particular antigen.

OBJECTIVE: To examine the relationship of skin test positivity to inhaled aeroallergens and socioeconomic status (SES).

METHODS: A total of 989 Montreal elementary school children were studied. A short questionnaire was completed by parents, and the children performed spirometry before and after a free-running exercise challenge. A subsample of 309 children underwent allergy skin prick tests to common inhaled aeroallergens. SES was established using parental occupation.

RESULTS: Higher social class was associated with an increased likelihood of having positive skin tests to cat and trees, while there was a trend towards an inverse relationship between SES and skin test sensitivity to cockroach and moulds. Reported history of asthma, hay fever or eczema were unrelated to SES.

CONCLUSIONS: The results of this study suggest differences in levels of exposure to different allergens by social class. From the public health point of view, communitybased allergen avoidance measures need to be adapted to social class.

Key Words: Allergen skin test positivity, Indoor pollution, Socioeconomic status

\section{Le statut socioéconomique et l'atopie chez l'enfant}

CONTEXTE : Les variations dans la prévalence des allergies dans les différents groupes socioéconomiques pourraient être dues soit aux différences dans le type des allergènes auxquels ces personnes sont exposées ou à des différences réelles de susceptibilité à la sensibilisation à tout antigène.

OBJECTIF : Examiner le rapport entre la positivité des cutiréactions aux aéroallergènes inhalés et le statut socioéconomique (SSE).

MÉTHODES : L'étude a porté sur un total de 989 écoliers des écoles primaires de Montréal. Les parents ont rempli un questionnaire bref. On a procédé à une spirométrie chez les enfants avant et après une épreuve de course libre. Ensuite, on a pratiqué des cutiréactions aux aéroallergènes inhalés courants sur un sous-échantillon de 309 enfants. Le statut socioéconomique a été établi d'après l'emploi des parents. RÉSULTATS : Une classe sociale plus élevée a été associée à une probabilité plus élevée de la positivité des cutiréactions aux chats et aux arbres, tandis qu'on a observé une tendance vers un rapport inversement proportionnel entre le SSE et la sensibilité aux blattes et aux moisissures. Les antécédents connus d'asthme, de rhume des foins ou d'eczéma n'avaient pas de rapport avec le SSE.

CONCLUSIONS : Les résultats de cette étude laissent croire que les niveaux d'exposition aux différents allergènes varient selon la classe socioéconomique. D'un point de vue de santé publique, les mesures d'éviction des allergènes dans la communauté doivent être adaptées aux classes sociales.

Correspondence and reprints: Dr Pierre Ernst, Respiratory Epidemiology Unit, McGill University, 1110 Pine Avenue West, Montreal, Quebec H3A 1A3. Telephone 514-398-6974, fax 514-398-8981, e-mail ernst@meakins.lan.mcgill.ca 
$\mathrm{T}_{\mathrm{s} e \mathrm{sin}}$ here is limited information on the relationship of socioeconomic status (SES) to different markers of atopy or allergy in children and the studies reported to date appear contradictory. A lack of association between SES and eczema was reported independently by Burr et al (1) and by Arshad and Hide (2). Most recently, Williams et al (3) reported increasing childhood eczema with lower social class among a cohort of children born in 1958 and examined at ages seven, 11 and 16 years. Freeman and Johnson (4) described a stepwise progression in the frequency of allergic syndromes (hay fever, rhinitis, atopic dermatitis, urticaria and asthma as reported by parents) from the lower SES group to the higher. Schenker et al (5) also reported a positive association between SES and a history of hay fever reported by parents in the United States. Differences in reporting behaviour among parents of different social classes may bias such studies, however. A recent study by Von Mutius and colleagues (6) examined the link between an objective measure of atopy, skin test positivity to common aeroallergens and the number of siblings. Skin test positivity decreased with an increase in the number of siblings; also large families are more common in lower SES strata.

Differences in skin test positivity to aeroallergens might be due to differences in the type of allergen encountered rather than actual susceptibility to sensitization to any particular antigen. In previous studies, the relationship of allergy skin test positivity and SES has been examined primarily among children with well-recognized allergic asthma. These relationships are not necessarily generalizable to other groups $(7,8)$.

During a population-based study of the determinants of respiratory health in Montreal school children, we therefore took the opportunity to examine the relevance of SES to skin test evidence of sensitization to various aeroallergens.

\section{PATIENTS AND METHODS Cross-sectional survey in the schools}

Study population: Eighteen schools were selected on the island of Montreal to represent a broad range of SES. One class from each school from each of grades 1 (ages five to seven years), 3 (ages eight and nine years) and 5 (ages 10 to 13 years) was selected. Study procedures were briefly described to each class and each child was provided with a letter, a short questionnaire and a consent form to be completed at home by a parent.

Of the 1274 children thus selected, the parents of 130 $(10.2 \%)$ refused participation for their children while a further $75(5.9 \%)$ children did not return the questionnaire. There were no important differences between participants and nonparticipants as to the age of the child, sex or race. Among families who refused to permit their child to participate in testing at school, but did return the questionnaire $(n=99)$, mothers were less likely to be currently smoking (18.8 versus $37.9 \%$ ) but no meaningful differences were seen in terms of respiratory symptoms, type of cooking and heating fuel used and pets in the home.

Lung function: In the school gymnasium, each subject's age, sex, height and weight were recorded and the children were asked whether they had experienced a respiratory tract infection within the previous week. Enquiries were made concerning current smoking among the grade 5 children. Spirometry was carried out with the child sitting and wearing nose clips using two Collins $10 \mathrm{~L}$ water-sealed spirometers (Warren E Collins, Massachusetts) according to current American Thoracic Society guidelines (9). The best forced expiratory volume in $1 \mathrm{~s}\left(\mathrm{FEV}_{1}\right)$ from any flow-volume curve, both at baseline and after exercise, was used for analysis (10). After a 5 min rest, heart rate was measured with a digital plethysmograph (Heart Rate Inc, California). Children were then asked to run around the gymnasium for 6 mins at a pace judged sufficient to attain at least $90 \%$ of the predicted maximal heart rate (11); heart rate was remeasured immediately on completion of exercise. Five and 10 mins after completion of exercise, spirometry was repeated on the same spirometer. Average temperature, relative humidity and percentage maximum heart rate attained were the same among children who did and those who did not demonstrate a $10 \%$ or greater fall in $\mathrm{FEV}_{1}$ after exercise. Subjects did not take part in the exercise test if they were excused from gym class or if their $\mathrm{FEV}_{1}$ was below $70 \%$ predicted. No specific instructions were given concerning the use of medications, including those for asthma. The exercise test was completed successfully in 989 children. Only 11 children $(1.11 \%)$ had been using a bronchodilator (eg, inhaled beta-agonist) in the days preceding the test.

\section{Subsample selected for study at home}

Study subjects: A subsample of children was chosen for more detailed investigation of risk factors for airway hyperresponsiveness. Children whose parents responded "yes" to the question: "Has a physician ever diagnosed asthma in your child?" and those whose $\mathrm{FEV}_{1}$ fell by $10 \%$ or more after exercise were first selected. For each of these children, the next child on the alphabetical class list of the same sex was chosen for comparison. If the parents of the child with asthma or exercise-induced bronchospasm (EIB) refused further participation, both this child and the one chosen for comparison were not studied further, while if a child chosen for comparison, that is without asthma or EIB, refused, the next appropriate child on the class list was selected. For 38 children with a history of asthma or EIB, a comparison subject of the same sex in the same class could not be obtained.

Respiratory questionnaires: Parents were interviewed on the child's history of eczema, hay fever, doctor-diagnosed asthma and housing conditions, including the current presence of pets (dogs, cats, birds, hamsters, mice, guinea-pigs) in the home. The questions asked on atopic-associated diseases were: "Has a doctor ever diagnosed eczema in this child?" (history of eczema); "Has this child ever had hay fever?" (history of hay fever); and "Has the child ever been diagnosed to have asthma?" (history of asthma).

Assessment of SES: Parents were also asked for a detailed employment history. The most recent occupation of parents was transformed into the corresponding codes of the Cana- 
dian Classification and Dictionary of Occupations (12). These codes were then converted into SES scores for the child based on income and education level for each occupation from the tables developed by Blishen and colleagues (13). The highest score from either parent was retained for analysis. The validity of questionnaire-reported work history is well documented (14).

Allergen skin prick testing: At the home visit, a drug history was taken to ensure that the child was not using any preparation that might interfere with a response. Solutions for testing comprised histamine $(1 \mathrm{mg} / \mathrm{mL})$, normal saline, Dermatophagoides pteronyssinus, Dermatophagoides farinae, mixed grass pollens, tree pollens, ragweed, mixed moulds, Aspergillus species, cat epithelium and cockroach. The mixed moulds comprised Alternaria tenuis, Aspergillus fumigatus, Aspergillus niger, Aspergillus oryzae, Aspergillus terreus, Hormodendrum hordei, Penicillium chrysoganum, Penicillium digitatum, Penicillium expansum and Penicillium notatum. Solutions for testing were obtained from Omega. Needles (26 gauge) were used to break the skin. The resultant wheal diameters were measured at right angles using Vernier calipers at 10 and 15 mins. A wheal at least $3 \mathrm{~mm}$ in either direction was taken as a positive response if the normal saline control showed no reaction (less than $1 \mathrm{~mm}$ ); otherwise, the size of the reaction was subtracted from the reaction of each allergen. If there was no positive response to histamine, skin testing was regarded as invalid.

Dust sampling and assays of house dust mite antigen: Dust samples were collected from the mattress and bedroom floor of the child. The upper surface of the child's bed mattress was vacuum cleaned for $1 \mathrm{~min}$ after removal of the bed linen. Dust was removed from the collection sock and $250 \mathrm{mg}$ of mattress dust was mixed with $10 \mathrm{~mL}$ radioallergosorbent test diluent $(1: 40 \mathrm{w} / \mathrm{v})$. The mixture was rocked overnight at room temperature. The next day 3 to $4 \mathrm{~mL}$ of extract was harvested from the extraction vessel and centrifuged to remove insoluble particulates. Extracts were stored at $-20^{\circ} \mathrm{C}$ until assayed. The assay was performed in flat-bottomed, Removawell strips assembled in a 96-well format (Immulon IV microtitre wells, Dynatech, Inc, Virginia). Capture antibody (5H8 C12 anti-p1 or 6A8 B10 anti-f1 monoclonals, University of Virginia, Virginia) was diluted (1:1000) in $200 \mathrm{mM}$ carbonate/bicarbonate buffer, pH 9.2. Detection antibody was a radiolabelled $\left({ }^{125} \mathrm{I}\right)$ cross-recognition monoclonal, which reacts with either P1 or F1 mite antigens (4C1, long wavelength ultraviolet [UVA]). Assay specificity was determined by the capture antibodies. Briefly, $100 \mu \mathrm{L}$ of capture antibody $(1 \mu \mathrm{g}$, 1:1000) was adsorbed to the surface of each microtitre well and incubated overnight at room temperature. Various concentrations of $D$ farinae or $D$ pteronyssinus allergen reference standards (calibrated at UVA) were delivered to a series of wells. Radiolabelled ( $\left.{ }^{125} \mathrm{I}\right) 4 \mathrm{C} 1$ monoclonal antibody was added to each well, incubated for at least $6 \mathrm{~h}$, washed and counted on a gamma-scintillation counter. The two-site assay yield radioactive counts were directly proportional to antigen content. The results were expressed as mass units of antigen per gram of collected dust (ie, ng antigen/g dust).
Air sampling for moulds: During the late fall and winter seasons, the airborne mould content of the children's homes was volumetrically sampled using Burkard volumetric air samplers (Burkard Manufacturing Company, Rickmansworth, England), with a Sabouraud dextrose agar media for nonspore forming moulds, and a gelatinated glycerine coated slide for spore forming moulds (Spores) (15). The two samplers drew, respectively, 15 and $11 \mathrm{~L} / \mathrm{min}$ and were run for 15 mins in the child's bedroom. Samples were then incubated for one to two weeks at $24^{\circ} \mathrm{C}$, and colony forming units (CFU) (for nonspore forming moulds) and spores were estimated. Species identification was done whenever possible. The moulds were classified as follows (16): those in the class Fungi Imperfecti with asexual stage and without known perfect stages of reproduction (allergenic moulds); those with an ability to change their metabolism and produce toxic metabolites as an alternative to other regulatory mechanisms (toxigenic moulds); those with variable peak concentrations in the cold and relatively warm seasons (seasonal moulds); those with constant concentrations throughout the year (nonseasonal moulds); spores more than $10 \mu \mathrm{m}$ in size (large spores); spores $10 \mu \mathrm{m}$ or less in size (small spores); and interior home moulds that are unlikely to have outside air as their source (Aspergillus and Penicillium). For each child's home the number of CFU and spores was summed (total moulds). The results of both spores and CFU were expressed as the number of $\mathrm{CFU} / \mathrm{m}^{3}$.

\section{STATISTICAL METHODS}

The outcome variables were childhood allergy skin tests, history of eczema and history of hay fever; the primary explanatory variable examined was SES.

The SES score obtained from parental occupation was used to group the children into quartiles. The unemployed were arbitrarily assigned a low SES score and grouped into quartile I, which represents families of low SES, and quartile IV, the highest SES.

The relationship of SES to the concentrations of various aeroallergens was examined by polynomial orthogonal contrasts after logarithmic transformation (SAS/STAT v 6, SAS Institute, North Carolina). The antilogarithms of the means for each SES quartile were calculated to express the results.

The relationship of the outcome variables to SES were examined using logistic regression models (17). Statistical significance of the regression coefficients was determined by the $\chi^{2}$ approximation to the likelihood ratio statistic.

Statistical analysis was carried out using SAS statistical software (Statistical Analysis System, v 6, SAS Institute).

\section{RESULTS}

Of the 269 children with either EIB or a history of asthma ( 80 of whom had a history of asthma alone), 187 (70\%) were visited at home. Of the 231 children chosen for comparison, 145 (63\%) were visited. Among children with EIB or a history of asthma, nonparticipants were more likely to be Caucasian $(86 \%$ versus $75 \%)$, to have mothers or fathers who were smokers at the time of the study ( $45 \%$ versus $37 \%$ and 
TABLE 1

Children's bedroom mould measurements according to socioeconomic status (SES) quartiles

\begin{tabular}{|c|c|c|c|c|c|}
\hline \multirow[b]{2}{*}{ Mould } & \multicolumn{4}{|c|}{ SES quartiles* } & \multirow[b]{2}{*}{$\begin{array}{c}\mathbf{P} \\
\text { value }^{\dagger}\end{array}$} \\
\hline & $\begin{array}{c}I \\
(n=81)\end{array}$ & $\begin{array}{c}\text { II } \\
(n=79)\end{array}$ & $\begin{array}{c}\text { III } \\
(n=79)\end{array}$ & $\begin{array}{c}\text { IV } \\
(n=80)\end{array}$ & \\
\hline Allergenic moulds & 78.49 & 57.54 & 55.63 & 40.52 & 0.0013 \\
\hline Toxigenic moulds & 19.83 & 12.80 & 15.43 & 8.26 & 0.0018 \\
\hline Seasonal moulds & 15.64 & 11.58 & 8.80 & 8.03 & 0.0066 \\
\hline $\begin{array}{l}\text { Nonseasonal } \\
\text { moulds }\end{array}$ & 67.49 & 64.88 & 61.18 & 46.25 & 0.0404 \\
\hline Large spores & 2.80 & 1.66 & 1.55 & 1.80 & 0.1602 \\
\hline Small spores & 69.33 & 54.34 & 52.68 & 40.88 & 0.0126 \\
\hline Aspergillus & 1.83 & 1.32 & 1.99 & 0.89 & 0.2043 \\
\hline Penicillium & 37.10 & 31.52 & 29.82 & 20.41 & 0.0113 \\
\hline Total moulds & 100.50 & 86.33 & 83.74 & 63.31 & 0.0190 \\
\hline
\end{tabular}

${ }^{*}$ Quartile I, least favoured and quartile IV most favoured SES based on parental occupation; ' Orthogonal polynomial contrasts; Results are expressed as mean number of colony forming units $/ \mathrm{m}^{3}$ for each SES quartile and adjusted for season in which samples were collected

TABLE 2

Children's bedroom dust mite antigen measurements according to socioeconomic status (SES) quartiles

\begin{tabular}{|c|c|c|c|c|c|c|}
\hline \multirow[b]{2}{*}{ Antigen } & \multirow[b]{2}{*}{ Number } & \multicolumn{4}{|c|}{ SES quartiles* } & \multirow{2}{*}{$\begin{array}{c}\mathbf{P} \\
\text { value }^{\dagger}\end{array}$} \\
\hline & & $\mathbf{I}$ & II & III & IV & \\
\hline \multicolumn{7}{|c|}{ Mattress mite } \\
\hline Df & 215 & 221.62 & 194.30 & 261.75 & 355.06 & 0.3729 \\
\hline $\mathrm{Dp}$ & 222 & 111.55 & 64.86 & 26.94 & 58.08 & 0.1444 \\
\hline \multicolumn{7}{|l|}{ Floor mite } \\
\hline Df & 221 & 68.58 & 98.64 & 66.68 & 111.76 & 0.6018 \\
\hline $\mathrm{Dp}$ & 222 & 71.14 & 47.74 & 13.30 & 56.96 & 0.3284 \\
\hline \multicolumn{7}{|l|}{ Total mite } \\
\hline Df & 214 & 245.41 & 223.26 & 204.95 & 415.81 & 0.3168 \\
\hline $\mathrm{Dp}$ & 222 & 153.22 & 101.85 & 44.31 & 95.37 & 0.1621 \\
\hline \multicolumn{7}{|c|}{ Pets in home, current (\%) } \\
\hline Cats & 332 & 13.7 & 14.6 & 27.8 & 23.7 & 0.0390 \\
\hline Any & 332 & 34.7 & 50.0 & 62.2 & 54.8 & 0.0020 \\
\hline
\end{tabular}

${ }^{*}$ Quartile I, least favoured, and quartile IV, most favoured SES, based on parental occupation; ${ }^{\dagger}$ Orthogonal polynomial contrasts for continous variables and $\chi^{2}$ trend test for categorical variables; Results are expressed as mean ng of antigen/g collected dust for each SES quartile and adjusted for season in which samples were collected. Df Dermatophagoides farinae; Dp Dermatophagoides pteronyssinus

$51 \%$ versus $44 \%$, respectively) or to have mothers who had smoked during pregnancy ( $43 \%$ versus $30 \%$ ). A history of asthma was more common among participants (45\%) than among nonparticipants (37\%). In the comparison group, differences in race and parental smoking between participants and nonparticipants were similar to, though less pronounced than, those described between participants and nonparticipants previously identified as reporting asthma or demonstrating EIB.

There were 309 (93.1\%) children with complete information on allergy skin tests and SES. The mean age of these children was 8.7 years; $53.9 \%$ were boys and $77.8 \%$ were
TABLE 3

The relationship of exercise-induced bronchitis and a history of asthma to childhood allergies

\begin{tabular}{lcc}
\hline Allergy skin test & Odds ratio & 95\% confidence interval \\
\hline Trees & 1.21 & $0.45-3.27$ \\
Cat & 2.44 & $1.10-5.45^{*}$ \\
Grasses & 1.21 & $0.56-2.63$ \\
$\begin{array}{l}\text { Dermatophagoides } \\
\text { farinae }\end{array}$ & 3.12 & $1.63-5.99^{*}$ \\
Dermatophagoides & 2.88 & $1.46-5.66^{*}$ \\
$\quad$ pteronyssinus & & \\
Ragweed & 1.78 & $0.95-3.36$ \\
Weeds & 1.27 & $0.35-4.58$ \\
Cockroach & 1.16 & $0.46-2.98$ \\
Moulds & 2.17 & $0.66-7.06$ \\
Any & 1.69 & $1.06-2.71^{*}$ \\
\hline
\end{tabular}

Adjusted for age and sex; ${ }^{*} P<0.05$

TABLE 4

The relationship of childhood allergies to socioeconomic status (SES)

\begin{tabular}{lcc}
\hline & Odds ratio & 95\% confidence interval \\
\hline Allergy skin test & & \\
Trees & $1.72^{*}$ & $1.03-2.88$ \\
Cat & $1.52^{*}$ & $1.04-2.22$ \\
Grasses & 1.19 & $0.81-1.77$ \\
Dermatophagoides & 1.11 & $0.83-1.49$ \\
$\quad$ farinae & & \\
Dermatophagoides & 1.09 & $0.81-1.48$ \\
$\quad$ pteronyssinus & & \\
Ragweed & 1.00 & $0.74-1.36$ \\
Weeds & 0.88 & $0.45-1.69$ \\
Cockroach & 0.82 & $0.48-1.41$ \\
Moulds & 0.71 & $0.41-1.22$ \\
Any & 1.20 & $0.94-1.53$ \\
Reported history of & & \\
Eczema & 0.95 & $0.71-1.28$ \\
Hay fever & 1.03 & $0.74-1.44$ \\
Asthma & 1.10 & $0.86-1.40$ \\
\hline
\end{tabular}

Odds ratio, adjusted for age and sex, is provided for 1 SD (19.2) increase in SES score. The lowest and highest scores were 22 and 101 , respectively. ${ }^{*} P<0.05$

Caucasian. The prevalences of positive skin tests were, in decreasing order of frequency: any allergen $38.5 \% ; D$ farinae $18.8 \%$; D pteronyssinus $16.8 \%$; ragweed pollen $16.8 \%$; cat $11.0 \%$; mixed grasses $9.7 \%$; cockroach $6.5 \%$; tree pollens $5.8 \%$; mixed moulds $4.9 \%$; and mixed weeds $3.2 \%$.

The concentration levels of allergenic, toxigenic, seasonal, nonseasonal and total moulds, as well as small spores and Penicillium, were highest among the least favoured (quartile I) and decreased progressively with higher SES (quartile IV) (Table 1). House dust mite antigens were not monotonically related to the SES quartiles, however (Table 2 ). On the other hand, the proportion of cats and pets in general was lowest among quartile I and increased progressively with higher SES (quartile IV) (Table 2). 
The relationship of skin tests to the combined outcome of EIB and a history of asthma is displayed in Table 3. Skin test positivity to cat, $D$ farinae, D pteronyssinus, as well as to any one allergen were significantly more likely to be present among subjects who reported asthma or demonstrated EIB.

The relationship of SES to allergy skin test results is illustrated in Table 4. There was an increased likelihood of positive skin test sensitivity to cat, trees and grasses in children with higher SES, and for cats and trees this achieved statistical significance. The likelihood of positive reactions to cockroach and mixed moulds was increased in children with lower SES, although this did not achieve statistical significance. Positive skin test results to any one allergen were more common in children with higher SES. Although the likelihood of having asthma as reported by parents appears to increase with higher SES, this did not achieve statistical significance. There was no obvious relationship of SES to history of eczema or hay fever.

\section{DISCUSSION}

While skin test positivity tends to be more frequent among subjects in higher socioeconomic circumstances (6), this depends at least partly on which skin test allergens are used. According to the pattern of exposure and sensitization observed in the present study, children from poor families appear more likely to live in homes with cockroaches and moulds and are less likely to own pets.

We are likely to have underestimated the relationship of

ACKNOWLEDGEMENTS: Pierre Ernst is Senior chercheur boursier, Fonds de la Recherche en Santé du Québec. This study was supported by the Medical Research Council of Canada and the Respiratory Health Network of Centres of Excellence.

\section{REFERENCES}

1. Burr M, Miskelly FG, Butland BK, Merrett TG, VaughanWilliams E. Environmental factors and symptoms in infants at high risk of allergy. J Epidemiol Community Health 1989;43:125-32.

2. Arshad SH, Hide DW. Effect of environmental factors on the development of allergic disorders in infancy. J Allergy Clin Immunol 1992;90:235-41.

3. Williams HC, Strachan DP, Hay RJ. Childhood eczema: disease of the advantaged? BMJ 1994;308:1132-5.

4. Freeman GL, Johnson S. Allergic diseases in adolescents I. Description of survey; prevalence of allergy. Am J Dis Child 1964;107:549-59.

5. Schenker MB, Samet JM, Speizer FE. Risk factors for childhood respiratory disease - the effect of host factors and home environmental exposures. Am Rev Respir Dis 1953;128:1038-43.

6. Von Mutius E, Martinez FD, Fritzsch C, Nicolai T, Reitmeir P, Thiemann HH. Skin test reactivity and number of siblings. BMJ 1994;308:692-5.

7. Menon P, Menon V, Hilman B, Stankus R, Lehrer SB. Skin test reactivity to whole body and faecal extracts of American (Periplaneta americana) and German (Blatella germanica) skin test positivity to SES based on the design of our study, which selected children for comparison from the same school and who were therefore more likely to live in the same neighbourhood. Thus, the odds ratios for the association we have presented are conservative estimates of the true relationship present in our study population.

Our results are in agreement with those of Menon et al (7), whose subjects (mostly under 20 years of age) from lower income families (less than US\$10,000) had a significantly higher skin test reactivity to cockroach allergens than those from families with an annual income of $\$ 11,000$ to $\$ 24,000$.

Among 315 urban children with chronic asthma from San Diego, California, Willies-Jacobo et al (8) found skin test results to one or both species of house dust mite in 122 of 158 (77\%) children in the lower SES group compared with 102 of $157(65 \%)$ children in the higher SES. Meanwhile, reactions to animal danders, pollens and moulds tended to be more frequent in children in the higher SES group.

\section{CONCLUSION}

The results of this study provide evidence suggesting differences in levels of exposure to different allergens by social class. Thus, studies linking atopy, as judged by the presence of positive skin prick reactions to aeroallergens, to socioeconomic class or to measures possibly associated with SES must be interpreted with caution. From the public health point of view, community-based allergen avoidance measures need to be adapted to the social class of the target population.

cockroaches in atopic asthmatics. Ann Allergy 1991;67:573-7.

8. Willies-Jacobo LJ, Denson-Lino JM, Rosas A, O'Connor RD,

Wilson NW. Socioeconomic status and allergy in children with asthma. J Allergy Clin Immunol 1993;92:630-2.

9. American Thoracic Society. Standardization of spirometry 1987 update. Am Rev Respir Dis 1987;136:1285-98.

10. Kanner RE, Schenker MB, Munoz A, Speizer FE. Spirometry in children. Methodology for obtaining optimal results for clinical and epidemiologic studies. Am Rev Respir Dis 1983;127:720-4.

11. Tsanakas JN, Milner RDG, Bannister OM, Boon WA. Free running asthma screening test. Arch Dis Child 1988;63:261-5.

12. Statistics Canada. Standard division: Standard Occupational Classification (1980). Catalogue 12-565E. Ottawa: Ministry of Industry, Science and Technology, 1980.

13. Blishen BR, Carroll WK, Moore C. The 1981 socioeconomic index for occupations in Canada. Can Rev Sociol Anthropol 1987;24:465-88.

14. Stewart WF, Tonascia JA, Matanoski GM. The validity of questionnaire-reported work history in live respondents. J Occup Med 1987;29:795-800.

15. Ogden E, Raynor G. Field evaluation of ragweed pollen samplers. J Allergy 1960;31:307.

16. Salvaggio J, Aukrust L. Mould-induced asthma, a postgraduate course presentation. J Clin Allergy Immunol 1981;68:327-46.

17. Kleinbaum DG, Kupper LL, Morgenstern H. Epidemiologic Research: Principles and Quantitative Methods. Belmont: Lifetime Learning, 1982:419-46. 


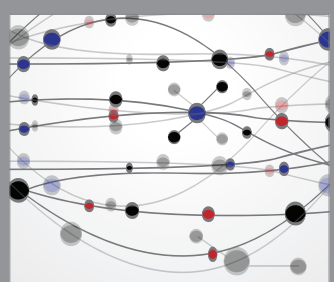

The Scientific World Journal
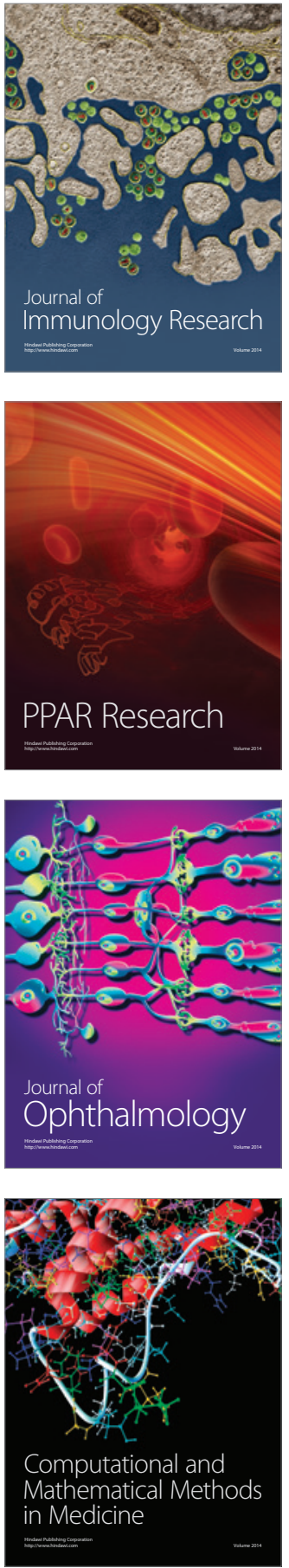

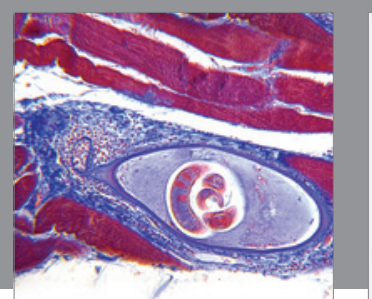

Gastroenterology Research and Practice

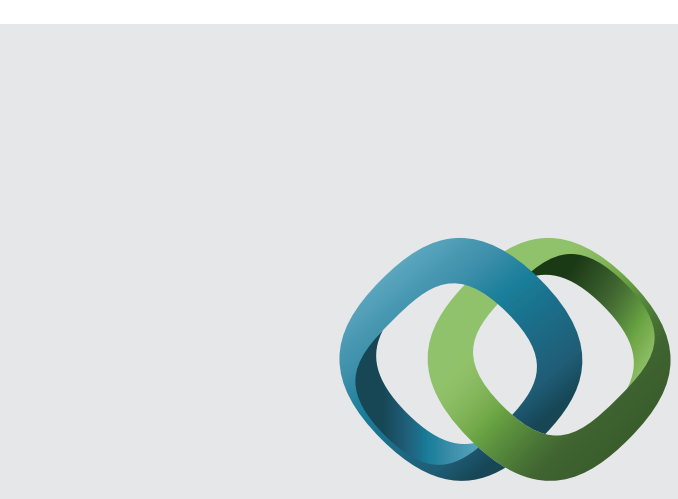

\section{Hindawi}

Submit your manuscripts at

http://www.hindawi.com
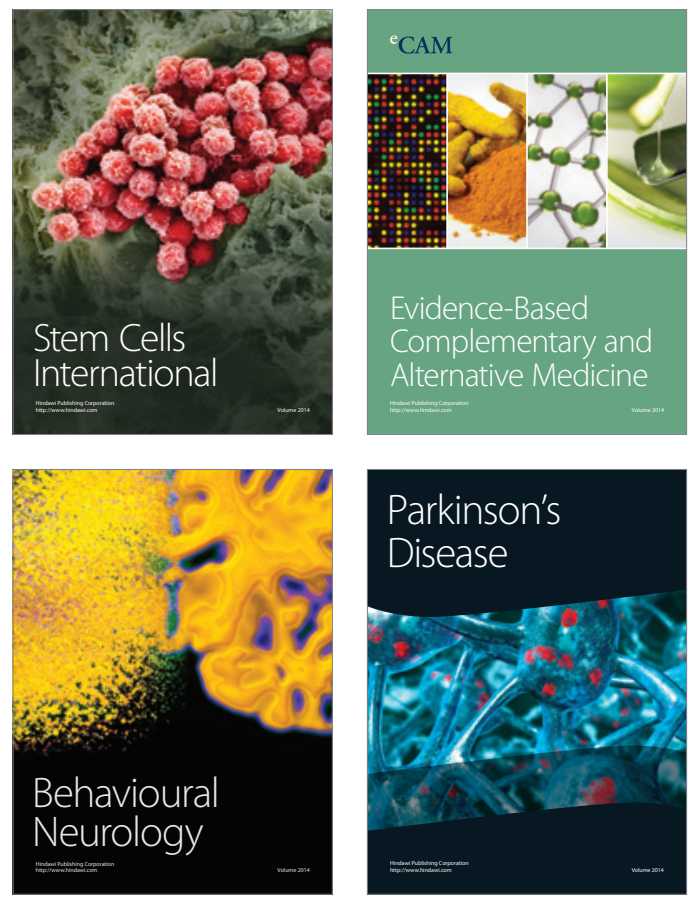
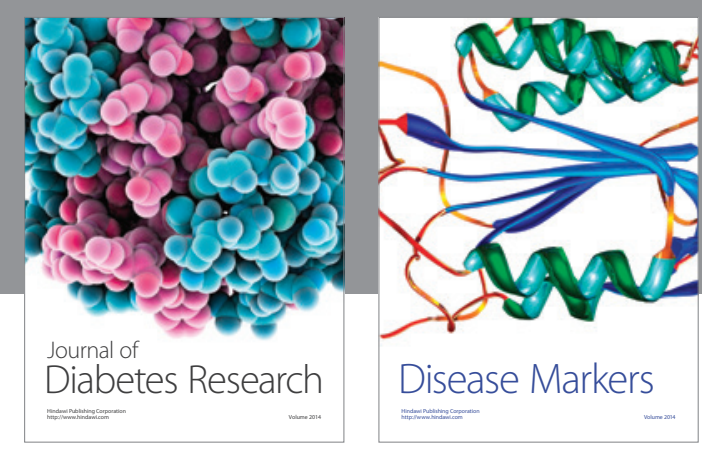

Disease Markers
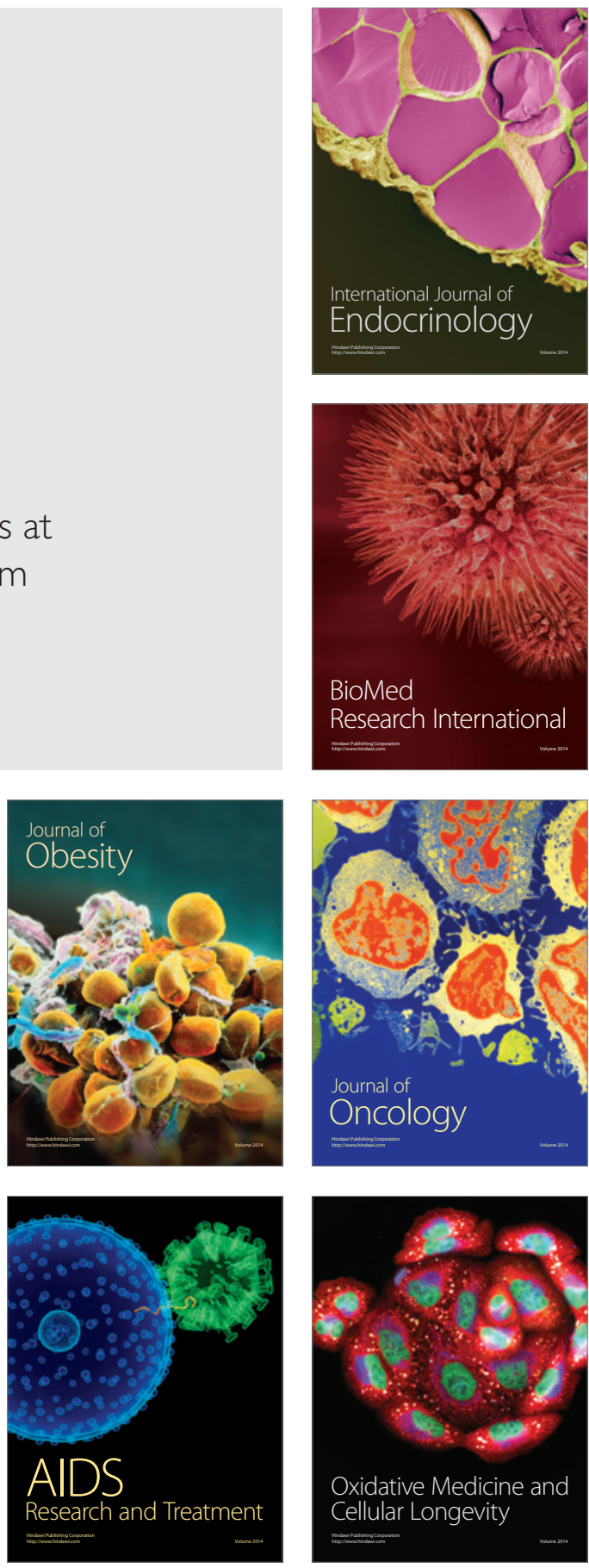